\title{
Theological imagination as hermeneutical device: Exploring the hermeneutical contribution of an imaginal engagement with the text
}

\begin{tabular}{|c|c|}
\hline $\begin{array}{l}\text { Author: } \\
\text { Anneke Viljoe }\end{array}$ & \\
\hline $\begin{array}{l}\text { Affiliation: } \\
\text { Department } \\
\text { Testament Stu } \\
\text { of Pretoria, Pr } \\
\text { South Africa }\end{array}$ & $\begin{array}{l}\text { f Old } \\
\text { dies, University } \\
\text { etoria, }\end{array}$ \\
\hline $\begin{array}{l}\text { Research Proj } \\
\text { Registration: } \\
\text { Project Leade } \\
\text { Geyser-Fouch } \\
\text { Project Numb }\end{array}$ & ect \\
\hline $\begin{array}{l}\text { Description: } \\
\text { Dr Anneke Vil } \\
\text { participating i } \\
\text { project, 'Old T } \\
\text { Wisdom Studi } \\
\text { Dr Ananda Ge } \\
\text { Department o } \\
\text { Studies, Facul } \\
\text { University of }\end{array}$ & $\begin{array}{l}\text { oen is } \\
\text { the research } \\
\text { estament } \\
\text { es, directed by } \\
\text { yser-Fouche, } \\
\text { Old Testament } \\
\text { y of Theology, } \\
\text { retoria. }\end{array}$ \\
\hline $\begin{array}{l}\text { Correspondin } \\
\text { Anneke Viljoe } \\
\text { anchri@mwe }\end{array}$ & $\begin{array}{l}\text { sauthor: } \\
\text { h, } \\
\text { co.za }\end{array}$ \\
\hline $\begin{array}{l}\text { Dates: } \\
\text { Received: } 29 \\
\text { Accepted: } 17 \\
\text { Published: } 08\end{array}$ & $\begin{array}{l}\text { lug. } 2015 \\
\text { an. } 2016 \\
\text { uly } 2016\end{array}$ \\
\hline $\begin{array}{l}\text { How to cite th } \\
\text { Viljoen A., 20 } \\
\text { imagination a } \\
\text { device: Explor } \\
\text { hermeneutica } \\
\text { of an imagina } \\
\text { with the text', } \\
\text { Studies/Theol } \\
72(4) \text {, a3172. } \\
\text { org/10.4102/l }\end{array}$ & $\begin{array}{l}\text { is article: } \\
6 \text {, 'Theological } \\
\text { hermeneutical } \\
\text { ing the } \\
\text { contribution } \\
\text { engagement } \\
\text { HTS Teologiese } \\
\text { gical Studies } \\
\text { ittp://dx.doi. } \\
\text { its.v72i4.3172 }\end{array}$ \\
\hline $\begin{array}{l}\text { Copyright: } \\
\text { (c) 2016. The } \\
\text { Licensee: AOS } \\
\text { is licensed un } \\
\text { Creative Com } \\
\text { Attribution Lic }\end{array}$ & $\begin{array}{l}\text { uthors. } \\
\text { S. This work } \\
\text { ler the } \\
\text { nons } \\
\text { ense. }\end{array}$ \\
\hline Read online: & \\
\hline 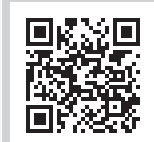 & $\begin{array}{l}\text { Scan this QR } \\
\text { code with your } \\
\text { smart phone or } \\
\text { mobile device } \\
\text { to read online. }\end{array}$ \\
\hline
\end{tabular}

In the past, biblical scholarship has neglected the hermeneutical contribution that an imaginal engagement with the text may make. The author's aim in this article was to develop theological imagination as a hermeneutical device. This was done by briefly considering the concurrence in the hermeneutic contributions of three interpreters of biblical texts, with specific regard to their understanding of biblical imagination. These were Walter Brueggemann, Paul Ricoeur and Ignatius of Loyola. Their hermeneutical contributions concur in their understanding of a biblically informed imagination, and it is specifically this aspect of the concurrence of their thought that was explored. An illustration from Proverbs 14:27, which draws on the metaphor and biblical motif of the fountain or source of life, was put forward to demonstrate how the concurrence in the contributions of these biblical interpreters may influence an imaginal engagement with the text.

\section{Introduction}

Concerning the role of imagination in the Christian life, O'Brien (2011:4) states 'our problem is not an overactive imagination. The real threat is a lack of imagination'. I tend to agree. This is not just true of the Christian life in general, but possibly also of biblical scholarship in particular. Schökel (1988:102) observes that 'in biblical exegesis there is a lack of imagination and perception rather than a surfeit'. Martin ${ }^{1}$ (2014:346) notes 'scholars ... tend to concentrate their attention upon ideational/rational content'. Thus, biblical scholars are more inclined to focus their engagement with the text on the rational aspects of the text to the detriment of an imaginal ${ }^{2}$ engagement with the Scriptures.

The reasons are numerous, including the influence of modernism with its attending emphasis on rationality and its high regard for precise methodological deliberations (Marsh 2004:24). The problem of Cartesian doubt paved the way for the modern inclination towards doubt. Especially after Freud, Marx and Nietzsche, who were dubbed by Ricoeur as the masters of the school of suspicion, there is a strong awareness of, and concern for the various ways in which persons, both individual and as groups, can be mistaken, often unconsciously (Ricoeur 2008:32-33; cf. Marsh 2004:24). I suspect that imagination has often been associated with the unconscious drives which motivate thought patterns, attitudes and behaviour. For this reason, imagination and its use as a hermeneutical device in biblical exegesis and scholarship is regarded with suspicion among academics. 'But imagination is not the opposite of reality or the enemy of truth' (O'Brien 2011:1). In fact, and here I fully agree with $\mathrm{O}^{\prime}$ Brien, 'we do ourselves an enormous disservice when we ignore the imagination (whether intentionally or accidentally) and only develop the intellect'. Schökel (1988:141) states: 'It is not right to say that understanding is objective and imagination is subjective. Both understanding and imagination are operations of the subject who contemplates and analyses'. ${ }^{3}$ Kind (n. d.) affirms that a long philosophical tradition exists of treating imagining as an inferior kind of perceiving. Gregersen (2003) insists that imagination is not a detached aptitude of human rationality, but rather that it is part and parcel, at the very heart, of human rationality.

1.Martin (2014:339-353) pleads for an approach to the text that will include a critical investigation of the affective dimension of the biblical text as part of a holistic hermeneutic approach.

2.In agreement with Marsh (2014:59), I prefer to use the more neutral term imaginal, as 'pertaining to the imagination' rather than terms such as imaginative or imaginary.

3.Of imagination and fantasy (the sub-creative art in the expression derived from the image), Tolkien (1947:24) claims that it is a natural human activity. He concludes: 'It certainly does not destroy or even insult Reason; and it does not either blunt the appetite for, nor [sic] obscure the perception of, scientific verity. On the contrary. The keener and the clearer is the reason, the better fantasy will it make.' Creative fantasy that is closely related to imagination, the human mind's capacity for forming mental images of things not actually present, is for Tolkien founded upon recognition of fact, but not slavery to it. 
I want to argue that reason and imagination can collaborate in a hermeneutical endeavour. My premise is that theological imagination may aid scholarly work and is inevitable when one works with such elusive subject matter that resists being fully grasped as metaphors, symbols and the symbolic reality which biblical texts project for its readers. Subject matter of this kind needs to be visited and revisited again and again. The aim of this article is to develop theological imagination as a hermeneutical device. ${ }^{4}$ Because biblical scholarship has in the past neglected the hermeneutical contribution that an imaginal engagement with the text may make, it currently deserves special attention, in the author's opinion. For this reason, the article focuses attention on this aspect of the expansion of the hermeneutic task (to include an imaginal engagement with the text), and for the moment ${ }^{5}$ the traditional, mostly exclusively historical critical, and rational engagement of the text will be set aside. ${ }^{6}$ My hope is that this will assist in the rediscovery of the rich meanings that are available to readers of the Bible. Ricoeur (1962:193) aptly describes the recovery of symbolism: 'Beyond the wastelands of critical thought, we seek to be challenged anew' ${ }^{7}$ These rich meanings are available to those in the present day who do not wish to go back to a pre-critical engagement with the text, nor want to get caught up in an exclusively critical engagement with the text (Nathan 2014:16).

I believe that such rich meanings are accessible to those who are willing to actively engage their imagination when reading biblical texts. Nevertheless, there are prerequisites. Barry \& Connoly $^{8}$ ([1982] 2009:58) observe that biblical literature is intended to 'inspire people's imaginations and enkindle their faith' and recommend that it be read as such. ${ }^{9}$ In the same vein, Heim (2013:28) draws our attention to Schökel's advice to readers and interpreters of biblical poetry: that they 'alert their imagination' (Schökel 1988:104), for '[w] hat has been written with imagination must be read with imagination' (Schökel in Heim 2013:28). Schökel (1988:104) adds: 'provided the individual has imagination and it is in working order ${ }^{\prime}{ }^{10}$

4.In this article my focus is on applied biblical hermeneutics rather than on gen.... philosophy. For an introduction to the theoretical issues in terms of generic philosophy pertaining to imagery and imagination, see Kind (n. d.) and for an introduction to the philosophy of the imagination see Gendler (2013).

5.I say 'for the moment', as I do not at all want to deny the contributions, and even necessity of, a historical critical engagement with the text. I do not want to narrow the hermeneutical endeavour again, this time solely in the opposite direction to exclude historical critical considerations, but due to constraints in time and space will focus here on how I would like to see the hermeneutical endeavour expanded or broadened to include an imaginal engagement with the text as well. My plea is or broadened to include as ina for a compleme the will broaden the hermeneutic endeavour to include an imaginal engagement with the text rather than a narrowing
enterprise that will exclude historical critical methods.

6.Barth ([1963] 1979:176-177) likewise calls for a broadening of the hermeneutic enterprise beyond the narrowing scope of historical critical readings of the biblical text.

7.Nathan (2014:16) uses Ricoeur's metaphoric statement '[b]eyond the desert of criticism, we wish to be called again' to designate the broadening of the hermeneutical endeavour to include more symbolic engagements with the text.

8.Barry \& Connoly work in the field of spiritual direction in the interface between the biblical text and the life of the spiritual directee. The imagination of the directee is one of the areas in which this interface is facilitated by the spiritual director.

9.Barth ([1963] 1979:176-177) likewise calls for a reading of the biblical text on its own terms taking into consideration the kerygmatic character of the biblical text.

10.Tolkien (1947:24) makes a valid point concerning fantasy that is also valid for an imaginal engagement with the text: It 'can, of course, be carried to excess. It can be ill done. It can be put to evil uses. It may even delude the minds out of which it came. But of what human thing in this fallen world is that not true?'
Kugel (2003:192) terms this way of reading ancient texts 'theological imagining' and explains that if ancient texts

are read in the right way - with sympathy and imagination, no condescension, only a relentless desire to enter - they can indeed come back to life, and their world, their way of seeing, can let us in to take the measure of things that are strange. (Kugel 2003:3, author's own italics)

The imaginal working operative in biblical texts is not limited to texts of poetry only, but is at work in all genres of biblical literature as Ricoeur (1981:3-4) points out, and even throughout the whole process of formation, transmission, and interpretation of the biblical text according to Brueggemann (2003:7). Naturally, the nature of the different biblical genres will determine an imaginal engagement. An imaginal engagement with poetic texts will be different from that of legal, narrative or apocalyptic texts. Due to the strong symbolic nature of apocalyptic texts the latter will, as a matter of course, allow for much more liberty in theological imagining whereas legal or narrative texts will naturally be more restrictive in their imaginal possibilities.

Thus, the article briefly explores the concurrence in the hermeneutic contribution of three interpreters of biblical texts, with specific regard to their understanding of biblical imagination. These interpreters are Walter Brueggemann, Paul Ricoeur and Ignatius of Loyola. Their hermeneutical contributions concur in their understanding of a biblically informed imagination, and it is specifically this aspect of the concurrence of their thought that will be explored. Brueggemann's insistence on the inevitability of imagination in the interpretive process represents the point of departure from which the other two contributions are examined. Ricoeur represents the philosophical foundation of such an endeavour. Ignatius of Loyola represents a practical answer to the question of how to go about an imaginal engagement with the text. An illustration from Proverbs 14:27 which draws on the metaphor and biblical motif of the source of life will be put forward to demonstrate how the concurrence in the contributions of these biblical interpreters may have an impact on an imaginal engagement with the text.

\section{Exploring the concurrence in the hermeneutic contribution of three imaginal interpreters of biblical texts Walter Brueggemann}

Brueggemann's insistence on the inevitability of imagination in the interpretive process represents the first concurrence. According to Brueggemann (2002:19), imagination is the vehicle for interpretation. Moreover, he believes that the biblical text both embodies and insists on the ongoing work of imaginative interpretation (Brueggemann 2003:xii). He points out that the Christian canon came about as a result of the 'work of tradition', which is the process of interplay between 'historical reportage' and 'canonical formation' (Brueggemann 2003:7). This defining enterprise 
of the biblical formation, transmission, and interpretation may be termed 'imaginative remembering' (Brueggemann 2003:7). He understands imagination to be the human aptitude for entertaining images of meaning and reality that are beyond the evident givens of observable experience. For him imagination is the hosting of 'otherwise' (Brueggemann 2002:17). Biblical literature 'is not merely descriptive of a commonsense world; it dares, by artistic sensibility and risktaking rhetoric, to posit, characterise and vouch for a world beyond the "common sense" in which Yahweh is the defining character (Brueggemann 2003:9). He understands that the biblical text enables a counter-imagination of the world $^{11}$ (Brueggemann 1993:18-25).

When interpreting the biblical text, the reader stands in this same line of risk-taking imaginal engagement, reading the text with an eye towards the world beyond the common sense which the text posits, characterises and vouches for. Brueggemann's (2002:17) insistence on two things marks his contribution in terms of expanding the hermeneutic enterprise to include an imaginal engagement with the text. Firstly, that imagination is inevitable in the interpretive process if interpretation is ever to be anything more than simple reiteration. Rather than mere reiteration, interpretation is 'the movement of the text beyond itself in fresh ways, often ways never offered until this moment of utterance' (Brueggemann 2002:17). He finds the transformative energy of the text in the 'interplay between the normative and the imaginatively playful' (Brueggemann 2003:xii, author's italics). Imagination is 'an inescapable process for those of us who insist that this old text is a contemporary word to us. We transport ourselves out of the twenty first century back to that ancient world or, conversely, we transpose ancient voices into contemporary voices of authority' (Brueggemann 2002:17).

Secondly, faithful imagination is characteristically not autonomous fantasy, but good-faith extrapolation (Brueggemann 2002:16). The affirmation that the Scriptures are inspired says more than we can understand, and pertains not only to the origin of the text, but to its transmission and interpretation as well (cf. Brueggemann 2002:24). The Spirit meets us afresh in our faithful reading in each new time, place and circumstance (Brueggemann 2002:16). The faithful affirmation that the biblical text is the Word of God is not a guarantee that an imaginal engagement and interpretation will be inspired, but it represents a point of departure from which the interpreter may be open to the whispering of the Spirit in, and through the text.

\section{Paul Ricoeur}

Ricoeurian hermeneutics, likewise, places a high value on the imagination. Ricoeur is interested in the role of figurative texts in the formation of human subjectivity and understands religious studies to be a hermeneutical inquiry into the imaginative potential of myth, symbol, and story to aid our efforts to exist with integrity (Wallace 1995:14). He finds 'in

\footnotetext{
11.Brueggemann (1993) terms this process the biblical text's 'funding' of a counterimagination of the world.
}

reading itself the key to the heuristic functioning of the productive imagination' of texts (Ricoeur 1981:2, author's italics). Ricoeur (1977:26) maintains that poetic texts are any literary texts that have the ability to disclose a view of a possible world that, in the process of reading, eclipses the tangible, objective world. They are imaginative literary constructions that by virtue of the refiguration of possibilities, reconstruct reality and invite the reader to inhabit this projected world by adopting those refigured possibilities as his or her own (Hall 2006:193).

According to Ricoeur (1981), the act of reading should be seen as:

the meeting point of the itineraries of meaning offered by the text as a production of fiction ... and the free course (parcours) of meaning brought about by the reader seeking "to apply" the text to life. (pp. 2-3)

The intersection between the text and life engenders the imagination according to the Bible (Ricoeur 1981:3). ${ }^{12}$ A Ricoeurian hermeneutic that focuses on the mediating capacity of texts presents a method of interpretation with the potential to supplement historical critical hermeneutical endeavours in order to come to a richer understanding of the biblical text. Precisely herein lay its contribution in terms of expanding the hermeneutic enterprise.

\section{Ignatius of Loyola}

One of the key characteristics of Ignatian spirituality is its deep appreciation of the imagination. The sixteenth century Spanish mystic grasped the important role of the imagination in an engagement with the biblical text. Living during the Renaissance, at the dawn of modernity (Marsh 2004:23), Ignatius was an excellent analytical thinker, familiar with the ideas of leading contemporary theologians and philosophers, with an advanced degree from the University of Paris which was one of the most esteemed European universities of his day (Fleming 2008:55). He balanced his analytical engagement with the biblical text with his remarkable imagination, described by Fleming (2008:55) as 'the mental quality of thought that drove his spiritual life'. In Ignatian spirituality this mental quality of thought came to be known as imaginative contemplation. Ignatius' main focus in imaginative contemplation was on an active engagement of the imagination with the biblical text as a means for spiritual formation. Through imaginative contemplation of the text the reader of the Bible is brought into contact with the reality of God that the text references. ${ }^{13}$

Ignatius believed that imagination has the capacity to facilitate a transformational encounter with God. This is

12.In 'The Bible and the imagination' Ricoeur (1981:3-4) indicates that narrative's capacity for re-describing reality could function as an exemplary paradigm to capacity for re-describing reality could function as an exemplary paradigm to demonstrate that the operation of parabolisation does not appear alone in the narrative-parable, but that it is implicitly at work everywhere else as the operation of the biblical form of imagination. Elsewhere I have applied Ricoeur's model of the re-describing capacity of narrative texts to Proverbs, even though proverbs are not
a narrative genre (cf. Viljoen 2013; Viljoen \& Venter 2013).

13.Elsewhere (Viljoen 2015; Viljoen \& Venter 2013) I described the referencing ability of biblical texts. 
where I deem Ignatius makes the greatest contribution in terms of expanding the hermeneutical endeavour beyond a narrow, exclusively critical engagement with the text. An imaginative contemplation of the text, or what I would want to call an imaginal engagement with the text, allows the person of God encountered in the text (or who is referenced in and through the text as we have seen with Ricoeur's contribution) to transform the areas of a person's life ${ }^{14}$ that go beyond where the intellect is able to (Fleming 2008:58). This is especially valuable for church pastors, spiritual directors and those concerned with sharing the Scriptures with others in the hope of a transformational encounter. It is a valuable tool for facilitating a transformative encounter through the text by actively engaging the imagination.

Next an explanation of how an imaginal engagement with the text occurs is illustrated from Proverbs 14:27. This is done in two steps by, firstly, considering Ricoeur's hermeneutic contribution as this is more philosophical and general and, secondly, considering the practical contribution which an Ignatian imaginative contemplation may make. In conclusion, the poetics of the text is briefly described to tie up a summary of an imaginal engagement with the text described in this article.

\section{An imaginal engagement of the text illustrated from Proverbs 14:27}

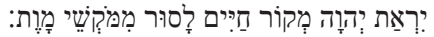 \\ The fear of Yahweh the source of life \\ to keep far from the snares of death.
}

\section{Ricoeur's hermeneutic contribution}

Ricoeurian hermeneutics invites the reader to make the issue at stake in the text their own. With symbolic texts such as Proverbs, what is said in the text, or the first order reference, leads the reader to discover what the text is about, i.e. the second order reference or 'about what' the text is. ${ }^{15}$ The text draws the reader into the symbolic world that it projects. Through appropriation, that is, the fourth and last pole of a Ricoeurian hermeneutic, ${ }^{16}$ the world that the text references for the reader may become the reader's very own world. It is this phase in the hermeneutic process that is considered here.

The proverb employs two powerful metaphors in order to imagine or picture for the reader a symbolic reality. Of symbols Ricoeur (1962:194) writes '[s]ymbol is a sign in this, that like every sign it intends something beyond and stands for this something'. The symbol of the source or fountain of life is a powerful metaphor for the fear of Yahweh, precisely because of the tangibility of the symbol that effectively carries the force of the metaphor. However, to come to an

14.Paulin-Campbell (2010) noted a significant connection between shifts in women's image of self and image of God that was facilitated by an imaginal engagement with the text.

15.On the referential intention of poetic text, cf. Reese ([1979] 1990); Viljoen \& Venter (2013).

16.For a description of the four poles of Ricoeur's hermeneutic, cf. Viljoen (2015). understanding of what the symbol refers to, and its intended meaning, does not occur instantaneously. 'Symbol invites thought' (Ricoeur 1962:193). This simple maxim says two things simultaneously. Firstly, the symbol invites; the reader does not posit the meaning, the symbol gives it. Secondly, what it gives the reader is something to think about, something to ponder or consider. The maxim suggests that everything has already been said enigmatically and, yet, at the same time it requires that the reader always has to begin over, begin again so that everything occurs in the dimension of thought (Ricoeur 1962:193).

The text is grounded in the concrete situation of the Ancient Near East, where the drier climate heightens the importance of water as a necessity for life. The source or fountain functioned within that society as a very well-known symbol of life and sustenance or nourishment. In the proverbial world that is referenced by the text, the fear of Yahweh is as indispensable as a source or fountain is to life. Heim (2013:354) affirms that the fear of Yahweh and the fountain or source of life together form a non-referring existential assertion, the fountain or source of life describing the fear of Yahweh more closely. Like water in its purest form, at the source, the fear of Yahweh is life-giving (Heim 2013:354).

The source or fountain (singular) of life is antithetically posed against the snares (plural) of death to indicate that there is only one source of life, but many snares of death. Berlin ([1985] 1992:135) describes the effect of parallelism as setting up relationships of equivalence between two propositions. In the case of the proverb two relationships are established, namely, one of equivalence between the fear of Yahweh and the purpose of keeping away from, and one of opposition between the source of life and snares of death. In the case of this proverb, the relationship is established between the two colons, comprising a single proposition. Heim (2013:354) illustrates this in tabulated form:

Berlin stresses that parallelism in itself does not have meaning but that it, 'like other formal features in a text, does help to structure the text and thereby has an impact on how its meaning is arrived at' (Berlin [1985] 1992:135, author's italics). She concludes 'parallelism calls attention to itself and to the message which it bears. Parallelism embodies the poetic function, and the poetic function heightens the focus on the message' (Berlin [1985] 1992:140). Thus, parallelism structures this text by simultaneously setting up a relationship of equivalence between the fear of Yahweh and the purpose of keeping away from the snares of death, as well as a relationship of opposition between the source of life and

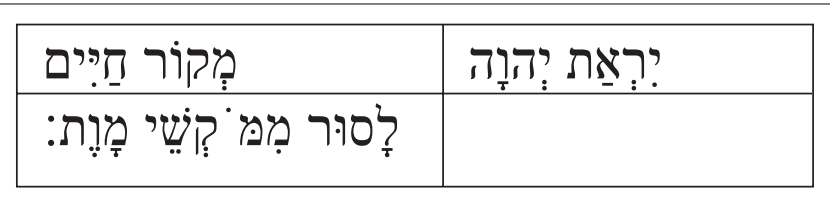

Source: Heim (2013:354)

Figure 1: The relationship established between the two colons comprising a single proposition. 
snares of death. The structure of the proverb testifies to the structure of the proverbial world in which there is a coherency between the fear of Yahweh and the purpose of keeping away

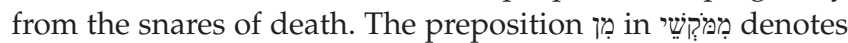
a sense of 'out of' or 'away from' indicating direction of movement in a spatial sense away from (Holladay 1988a:200) the snares of death. In combination with the metaphoric employment of the motif of the source of life, the benefit of

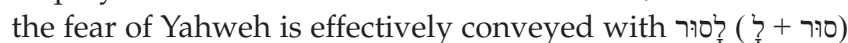
the infinitive construction designating a purpose clause; the fear of Yahweh is for, or has the purpose of keeping one far from the snares of death. In the symbolic-textual world of Proverbs the fear of Yahweh, as also in the immediately preceding proverb (Prov. 14:26), provides safety.

The idea that is expressed seems to be that the fear of Yahweh directs the righteous-wise person's movement, giving expression to the anthropocentric viewpoint of this proverb that places considerable emphasis on a person's own role in escaping misfortune (Boström 1990:217-218). In the symbolic world constructed in the book for its readers, a person may, through the fear of Yahweh, escape the snares of death. Boström (1990:217-218) notices in the snares of death a covert reference to the fate of the wicked-fool that is brought on by their own behaviour. With the purpose of keeping the righteous-wise out of the snares of death, the single source of life is contrasted with the many snares that may ensnare a person. Heim (2013:355) notes the symbolic reference of the snares of death: 'mortal danger, even hazards that are far from obvious to the uninitiated'. Here, the reader of Proverbs glimpses a world beset with many dangers that can ensnare a person, but at the same time is offered a view of the single source of protection, that is, the fear of Yahweh.

It is also worthwhile at this stage to consider other textual references that may contribute to a richer understanding of the text under consideration. Sandoval (2006:6) notes that the book of Proverbs constructs for its readers a 'complicated symbolic moral world' ${ }^{17}$ If through the first order reference the text aims at a second order reference, a symbolic reality that the text hopes the reader will appropriate as his or her own, then not just the single proverb, but the book as a whole is concerned with a larger symbolic-textual reality. ${ }^{18}$

The almost identical wording of this proverb and Proverbs 13:14 have been noted. ${ }^{19}$ The wording of Proverbs 13:14 is exactly the same as the wording in 14:27, except that

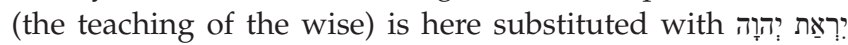
(the fear of Yahweh), and both are compared to the source of life that keeps one far from the snares of death. The result of the variant repetition is that the teaching of the wise is

17.Sandoval (2006) investigates the discourse of wealth and poverty in the book of Proverbs in terms of its figurative or metaphoric quality.

18.In fact, this can be expanded to include the whole of the Bible which projects richly multivalent and polyphonic symbolic reality through the various books and genres, theological stances and perspectives (cf. Ricoeur (1955:224). Due to space limitations I will focus here only on other textual references in Proverbs, but the 7:38 comes to mind, which could be very fruitful texts to explore and may yield rich biblical symbolic meaning.

19.Murphy (1998:106); Heim (2013:353-358). explicitly identified with the fear of Yahweh, and is even interchangeable (Heim 2013:356), ${ }^{20}$ indicating that the fear of Yahweh is not to be divorced from genuine wisdom. The difference in focus between the two proverbs is that this variant appeals to the reader's self-motivation to adhere to the received standards of the divine will, whereas Proverbs 13:14 recommends the value of somebody else's teachings, namely, those of the wise (Heim 2013:355). In the symbolic world sketched for the reader in Proverbs, the teaching of the wise and the fear of Yahweh are not opposed to each other but are united (cf. Prov. 1:7 and 9:10) in keeping the righteouswise far from the snares of death. With this precept, the proverb sets up an interconnectedness between the teaching of the wise and the fear of Yahweh, ${ }^{21}$ as is also the case in Proverbs 15:33 where instruction in wisdom is connected with the fear of Yahweh.

It is not difficult to see why scholars ${ }^{22}$ group verse 26 and 27 together since the theme of both is the fear of Yahweh. Heim (2001:184) also notes the fact that 'both display synonymoussequential parallelism, and the scarcity of synonymous parallelism in this collection suggests that whenever two verses stand together this may be intentional'. In combination, verses 26 and 27 vividly paint the fear of Yahweh as a place of refuge and a source of life, that is, a sphere of secure safety and nourishing sustenance. Together they invite the reader to inhabit the safe sphere that the fear of Yahweh provides, that is, to appropriate for themselves the fear of Yahweh. Within the broader structure of the chapter these proverbs inform the meaning of the other fear of Yahweh proverb (Prov. 14:2), in which the reader is told that to walk in straightness is to be safe and secure, and that it is a matter of life or death also for the next generation.

\section{An Ignatian imaginative contemplation}

Ignatian imaginative contemplation opens up the text for the reader to experience (not just think about) the metaphors or symbols in the text. Two striking metaphors are at the heart of the proverb: the fountain of life and the snares of death. Fishbane (1992) describes the well of living water as a biblical motif and quotes Talmon on the matter of motif:

A literary motif is a representative complex theme which recurs within the framework of the Old Testament in various forms and connections. It is rooted in an actual situation of anthropological or historical nature. In its secondary literary setting, the motif gives expression to ideas and experiences inherent in the original situation, and is employed to reactualize in the audience the reactions of the participants in the original situation. The motif ... is not a mere reiteration of the sensations involved, but rather a heightened and intensified representation of them. (Talmon in Fishbane 1992:3)

20.By investigating the variant repetitions within their respective textual contexts as part of proverbial clusters, Heim (2013:355-358) formulates possible scenarios for discerning the creative editorial process at work in the book of Proverbs. His contribution also sheds some light on the debate as to the question
theological re-interpretation of supposedly older non-Yahwistic proverbs.

21.Venter (1999:710) picks up on this interconnectedness and groups Proverbs 13:1414:27 into a unit under the unifying theme of the benefit of wisdom.

22.Fox (2009:583); Murphy (1998:106); Garrett (1993:145). 
He focuses attention on the biblical motif as a concrete fact and a religious metaphor (Fishbane 1992:4). The concrete nature of מָּז is is the construct state, a spring, fountain, or source $^{23}$ (Holladay 1988b:212) was appreciated as a source of life and nourishment in the Ancient Near East (Fishbane 1992:4). 'The primordial character of natural springs ... from which water bursts forth from the depths of the earth, should not be forgotten' (Fishbane 1992:4). The metaphor finds its very strength in the tangibility of the vehicle (the source of life). Opposed to the source of life in the proverb are the snares of death. This is also a very vivid metaphor which was well known among the peoples of the Ancient Near East, since it was based on the concrete situation prevailing at the time. A מוֹק w, snare was any device used to capture or ensnare

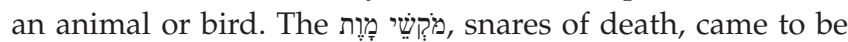
used mostly in its metaphoric sense of entrapment (Holladay 1988c:187) and is another biblical symbol. ${ }^{24}$

Ignatius would invite the reader of the text to try to imagine himself or herself as an active participant in the text. This may best be facilitated in three steps.

1. By employing their senses imaginally, readers of the text may gain experiential access to the metaphor(s) employed by the text.

After alerting their imaginations readers may ask themselves: What can I see in the text? What can I hear? What can I smell? What can I feel? What can I taste? In this way, the metaphors may come alive to readers as the text intended it.

2. Next the reader may ask: What do I experience as a result of the imaginal engagement of the text through the mediation of my senses?

With regard to the sample proverb, the experience of the source of life will, guided by the text, ${ }^{25}$ most probably be a positive one, whereas the experience of the snares of death will most probably be a negative experience. Here readers can give rein to their imaginations in calling up associations from their life environments that the symbols in the text call forth. What things in the reader's life experience seem restrictive, even unexpectedly ensnaring? How can this be brought into relation with the fear of Yahweh that is the source of life? How is the fear of Yahweh in their lives to be accessed as a source of life? Hildebrandt (1992:443) points out that the antithetic poetic structure, so frequently used by the sages, unleashes a powerful motivation combination: approach + avoidance. That which is good is to be approached, whereas that which is not good is to be avoided. By using two powerful metaphors the proverb combines both an approach and an avoidance motivation to persuade the reader of the value of the fear of Yahweh. The proverb encourages approach toward, or favourable reception of, the good, and at the same time persuades avoidance and rejection of the bad.

23.For other occurrences of the motif cf. Psalms $36: 10$; Jeremiah $2: 13$; $17: 13$; Proverbs 10:11; 13:14; John 4:10; 7:38.

24.For other occurrences of the symbol cf. 2 Samuel 22:6; Psalm 18:6; Proverbs 13:14.

25.With regard to an affective reading of the text, Martin (2014:340, 345) anticipates a charge of subjectivity that is equally valid for an imaginal engagement with the text. As a remedial he cautions that the reader stays close to the text.
3. Next the reader may also want to ask: What insight have I gained about myself, God, the world or life and others through this imaginal experiential engagement with the text?

What decision does the text want me to take; how will I let this imaginal engagement with the text affect my practical living? In this way, the illocutionary force of the text may be accessed and the reader may respond in a way fitting and appropriate to his or her own personal situation.

\section{Proverb poetics}

In conclusion, the poetics of the proverb may be described in the following way: the proverb employs two powerful metaphors, the literary motif of the source or fountain of life and the symbol of the snares of death, both grounded in the concrete situation of the Ancient Near East. The dryer climate heightens the importance of water as a necessity for life. The source or fountain functioned within that society as a very well-known symbol of life and sustenance or nourishment. The motif of the source of life is a powerful metaphor for the fear of Yahweh, precisely because of the tangibility of the symbol that effectively carries the force of the metaphor. Together with the metaphoric utilisation of the motif of the source of life, the benefit of the fear of Yahweh is effectively conveyed with the infinitive construction designating a purpose clause, namely that the fear of Yahweh is intended for keeping the reader far from the snares of death. Parallelism structures the text by simultaneously setting up a relationship of equivalence between the fear of Yahweh and the purpose of keeping the reader away from the snares of death, as well as a relationship of opposition between the source of life and the snares of death.

\section{Concluding remarks}

Brown (1999:xi-xii) rightly states that 'communities of faith have no option except to imagine themselves, informed by faith and understanding, living within the formative and normative contours of the biblical world'. This is true both for communities of faith as well as for individual Christians who regard the Scriptures as normative for their lives. He continues:

Such imagination is no flight of fancy. To the contrary, Christians are, in the words of Luke Timothy Johnson, called to a life of 'imagining the world Scripture imagines,' a life guided by faithful and moral imagination. (Brown 1999:xi-xii)

Biblical scholars have in the past tended to focus more on a rational engagement with biblical texts to the detriment of an imaginal engagement with the Scriptures, neglecting the hermeneutical contribution which an imaginal engagement with the text may make. Theological imagination may aid scholarly work and is inevitable when one works with such elusive subject matter that resists being fully grasped as metaphors, symbols and the symbolic reality which biblical texts project for its readers. Subject matter of this kind needs to be visited and revisited again and again. It was the author's 
aim in this article to develop the concept of imagination as a hermeneutical device.

This was done by briefly considering the concurrence in the hermeneutic contribution of three interpreters of biblical texts, with specific regard to their understanding of biblical imagination. These were Walter Brueggemann, Paul Ricoeur and Ignatius of Loyola. Their hermeneutical contributions concur in their understanding of a biblically informed imagination, and it is specifically this aspect of the concurrence of their thought that was explored. An illustration from Proverbs 14:27 that draws on the metaphor and biblical motif of the fountain or source of life was put forward to demonstrate how the concurrence in the contributions of these biblical interpreters may influence an imaginal engagement with the text.

\section{Acknowledgements Competing interests}

The author declares that she has no financial or personal relationships which may have inappropriately influenced her in writing this article.

\section{References}

Barry, W.A. \& Connoly, W.J., [1982] 2009, The practice of spiritual direction, HarperOne, New York.

Barth, K., [1963] 1979, Evangelical theology: An introduction, William B. Eerdmans Publishing Company, Grand Rapids, MI.

Berlin, A., [1985] 1992, The dynamics of Biblical parallelism, Indiana University Press, Bloomington, $\mathrm{CA}$.

Boström, L., 1990, The God of the sages: The portrayal of God in the book of Proverbs, Almqvist \& Wiksell International, Stokholm.

Brown, W.P., 1999, The ethos of the cosmos: The genesis of moral imagination in the Bible, Eerdmans, Grand Rapids, MI.

Brueggemann, W., 1993, The Bible and postmodern imagination: Texts under negotiation, SCM Press, London.

Brueggemann, W., 2002, 'Biblical authority: A personal reflection', in W. Brueggemann, W.C. Placher \& B.K. Blount (eds.), Struggling with scripture, pp. 5-31, Westminster John Knox Press, Louisville, KY.

Brueggemann, W., 2003, An Introduction to the Old Testament: The canon and Christian imagination, Westminster John Knox Press, Louisville, KY.

Fishbane, M.A., 1992, 'The well of living water: A Biblical motif and its ancien transformations', in M.A. Fishbane \& E. Tov (eds.), with the help of W.W. Fields, Sha'arei Talmon: Studies in the Bible, Qumran, and the Ancient Near East presented to Shemaryahu Talmon, Eisenbrauns, Warsaw.

Fleming, D.L., 2008, What is Ignatian spirituality?, Loyola Press, Chicago, IL.

Fox, M.V., 2009, Proverbs 10-31: A new translation with introduction and commentary, Yale University Press, New Haven, CT.

Garrett, D.A., 1993, Proverbs, Ecclesiastes, song of songs (The new American commentary, volume 14), B \& H Publishing Group, Nashville, TN.

Gendler, T., 'Imagination', in E.N. Zalta (ed.), The Stanford Encyclopaedia of Philosophy (Fall 2013 edition), viewed 21 November 2015, from http://plato.stanford.edu/ archives/fall2013/entries/imagination/

Gregersen, N., 2003, 'The naturalness of religious imagination and the idea of Revelation', Ars Disputandi 3(1), 261-287.

Hall, D.W., 2006, 'The economy of the gift: Paul Ricoeur's poetic redescription of reality', Literature \& Theology 20(2), 189-204. http://dx.doi.org/10.1093/litthe/frl015

Heim, K.M., 2001, Like grapes of gold set in silver: an interpretation of proverbial clusters in Proverbs 10:1-22:16, De Gruyter, Berlin.
Heim, K.M., 2013, Poetic imagination in Proverbs: Variant repetitions and the nature of poetry, Eisenbrauns, Winona Lake, IN.

Hildebrandt, T., 1992, 'Motivation and antithetic parallelism in Proverbs 10-15', Journal of the Evangelical Theological Society 35(4), 433-444.

Holladay, W.L., 1988a, $s$ v wִ, A concise Hebrew and Aramaic lexicon of the Old Testament, Brill, Leiden.

Holladay, W.L., 1988b, sv מקוז A concise Hebrew and Aramaic lexicon of the Old Testament, Brill, Leiden.

Holladay, W.L., 1988c, s v שipin, A concise Hebrew and Aramaic lexicon of the Old Testament, Brill, Leiden.

Kind, A., n. d., 'Imagery and imagination', Internet encyclopedia of philosophy: A peerreviewed academic resource, viewed 21 November 2015, from http://www.iep. utm.edu/imagery/

Kugel, J.L., 2003, The God of old: Inside the lost world of the Bible, Free Press, New York.

Marsh, R.R., 2004, 'Looking at God looking at you', The Way 43(4), 19-28.

Marsh, R.R., 2014, 'Teaching spiritual direction as if God were real', The Way 53(4), $57-67$.

Martin, L.M., 2014, 'Rhetorical criticism and the affective dimension of the biblical text', Journal for Semitics 23(2i), 339-353.

Murphy, R.E., 1998, Proverbs (Word Biblical Commentary Volume 22), Thomas Nelson Inc, Nashville, TN.

Nathan, E., 2014, 'Beyond the desert: re-engaging the Bible today', in R. Beringer R. Burggraeve, E. Nathan \& M. Steegen (eds.), Provoked to speech: Biblical hermeneutics as conversation, pp. 15-25, Peeters, Leuven.

O'Brien, B.J., 2011, 'Can you imagine? Why imagination is crucial to the Christian life' in ChristianityToday/ChristianBibleStudies.com, viewed 6 May 2015, from http:// www.christianitytoday.com/biblestudies/articles/theology/canyouimagine. html?start=1

Paulin-Campbell, A.R., 2010, 'The impact of imaginal and dialogical (relational) processes in the Spiritual Exercises, on image of self and image of God in women making the Nineteenth Annotation Retreat', PhD dissertation, University of KwaZulu-Natal, Pietermaritzburg.

Reese, J.M., [1979] 1990, 'Can Paul Ricoeur's method contribute to interpreting the book of Wisdom?' in M. Gilbert (ed.), La sagesse de l'Ancien Testament, pp. 384-396, Leuven University Press, Leuven.

Ricoeur, P., 1962, 'The hermeneutics of symbols and philosophical reflection' International Philosophical Quarterly 2(2), 191-218. http://dx.doi.org/10.5840/ ipq19622210

Ricoeur, P., 1977, 'Toward a hermeneutic of the idea of revelation', Harvard Theological Review 70, 1-37. http://dx.doi.org/10.1017/S0017816000017600

Ricoeur, P., 1981, 'The Bible and the imagination' in H.D. Betz (ed.), The Bible as a document of the university, pp. 1-20, Scholars Press, CA, viewed 28 February 2012, from http://www.fondsricoeur.fr/photo/Ricoeur $\% 20 \% 20$ The $\% 20$ Bible $\% 20$ and $\% 20$ the $\% 20$ Imagination.pdf

Ricoeur, P., 1995, 'Naming God', in M.I. Wallace (ed.), transl. D. Pellauer, Figuring the sacred: religion, narrative and imagination, pp. 217-235, Fortress, Minneapolis, MN.

Ricoeur, P., 2008, Freud and philosophy: An essay on interpretation, transl. D. Savage, Motilal Banarsidass, Delhi.

Sandoval, T.J., 2006, The discourse of wealth and poverty in the book of Proverbs, Brill, Leiden.

Schökel, L.A., 1988, A manual of Hebrew poetics, Pontifical Biblical Institute, Rome.

Tolkien, J.R.R., 1947, On fairy-stories, Oxford University Press, pp. 3-84, viewed 15 June 2015, from http://www.excelsiorclassical.org

Venter, P.M., 1999, 'Spreuke', in W. Vosloo \& J.J. Van Rensburg (Reds.), Die Bybellennium eenvolumekommentaar: Die Bybel uitgelê vir eietydse toepassing, Christelike Uitgewersmaatskappy, Vereeniging.

Viljoen, A., 2013, 'An exploration of the symbolic world of Proverbs 10:1-15:33 with specific reference to "the fear of the Lord"', PhD thesis, University of Pretoria, Pretoria.

Viljoen, A., 2015, 'The structuring considerations of a Ricoeurian hermeneutic employed in a reading of Proverbs 14:2', HTS Teologiese Studies/Theological Studies 71(3), Art. no 2849, 7 p. http://dx.doi.org/10.4102/hts.v71i3.2849

Viljoen, A. \& Venter, P.M., 2013, 'An exploration of the symbolic world of Proverbs 10:1-15:33 with specific reference to "the fear of the Lord"', HTS Teologiese
Studies/Theological Studies 69(1), Art. no 2008, 6 p. http://dx.doi.org/10.4102/ Studies/Theologica
hts.v69i1.2008

Wallace, M.I., 1995, 'Introduction', in M.I. Wallace (ed.), transl. D. Pellauer, Figuring the sacred: religion, narrative and imagination, pp. 1-35, Fortress, Minneapolis, MN. 